Article

\title{
Fostering Urban Sustainability through the Ecological Wisdom of Traditional Settlements
}

\author{
Naji Akbar ${ }^{1}$, Ismaila Rimi Abubakar 2,*(i) and Adel Saleh Bouregh ${ }^{1}$ (D) \\ 1 Department of Interior Architecture, College of Architecture and Planning, Imam Abdulrahman Bin Faisal \\ University, Dammam 31441, Saudi Arabia; nakbar@iau.edu.sa (N.A.); asbouregh@iau.edu.sa (A.S.B.) \\ 2 College of Architecture and Planning, Imam Abdulrahman Bin Faisal University, \\ Dammam 31441, Saudi Arabia \\ * Correspondence: irabubakar@iau.edu.sa
}

Received: 19 October 2020; Accepted: 27 November 2020; Published: 1 December 2020

check for updates

\begin{abstract}
Several African and Asian countries have embarked on building new towns to address urbanization challenges such as crowded cities, slums, and pressure on existing infrastructure. These projects have been criticized for being inadequate in fostering environmental sustainability. Based on a desk study, this article reviews the environmental sustainability challenges of these projects and recommends some ecologically embedded practices of traditional settlements that wonderfully survived for many centuries with little adverse social and environmental impacts yet offered opportunities for urbanism. The article discusses how the architecture, urban form, and green infrastructure of traditional settlements present excellent cases of ecological wisdom and embeddedness where the local ecosystems are respected, and every human activity, including the creation of the built environment, is defined by the ecological allowances, where resilience is part of the built environment at both micro and macro scales, and where humanity and nature are equal stakeholders living in unison. The article concludes that these instances of successful ecological embeddedness in traditional settlements can provide lessons for contemporary cities to ponder when envisioning more sustainable built environments for the present and future generations.
\end{abstract}

Keywords: architecture; ecological wisdom; environmental sustainability; green infrastructure; new towns; traditional settlements; urban form

\section{Introduction}

Cities have been growing at an unprecedented rate since the middle of the 20th century. Within three decades (2000-2030), global urban expanse is estimated to nearly double from $652,825 \mathrm{~km}^{2}$ to $1,210,475 \mathrm{~km}^{2}$ [1]. While constituting half of humanity in 2007, urbanites are expected to reach $68 \%$ of the global population by 2050 [2]. African and Asian countries could add $90 \%$ of the expected 2.5 billion increase in the global urban population from 2015 to 2030 [3]. This unprecedented level of urbanization is resulting in overcrowded cities, slums, and overwhelmed infrastructure. To address these urbanization challenges, stimulate economic growth, and create an image of modernization and development, several African and Asian countries have embarked on building new towns within existing major cities, on the edge of cities, or as standalone satellite towns. In Africa, more than 40 new towns are being constructed or planned [4], as are several others in Asia [5,6]. These new towns are labeled contemporary new towns (CNTs) because they have largely come into existence within the last two decades [5,7]. Inspired by the globalized "world class" and smart city vision, the real estate companies that promote these new towns guarantee the provision of modern housing, advanced facilities, and businesses such as those in Western cities [8]. 
However, CNTs have been criticized for being modernist projects that adopt a rigid Western-style model that over-rely on the technical expertise of foreign architects and engineers [9-11]. They have been described as speculative "urban fantasies" lacking adaptation to the local context, having little regard for social equity, and disrupting the informal sector and local populations [12-14]. They are also perceived as elitist and superficial projects unsuitable for addressing urban problems because they neglect blights in existing cities and exacerbate social exclusion and spatial segregation [11,12]. Other observers see the CNTs as profit-driven projects championed by real estate companies without regard for environmental sustainability [15-18]. Modernist urban plans that emphasize technological advances, increased exploitation of resources, and top-down control through a strict hierarchy exacerbate ecological challenges and make cities less sustainable. Thus, the literature convincingly suggests that there are several adverse environmental and social impacts arising out of these projects. Given these challenges, one tends to question if the idea of "progress" that advocates for the creation of new towns with little consideration for environmental sustainability is inevitable, or even desirable.

Cities cannot be considered apart from the ecosystem in which they exist because of the organized interactions between people and the natural environment, where nature and culture are not separate, and none is superior to the other [19]. In many instances, humanity attempts to live with nature, serving as a great source of sustenance and finding meaning and purpose in life, as well as emotional nourishment and spirituality. To sustainably undertake any human activities, nature has a clue in the form of ecological wisdom of developing a mutually beneficial relationship between people and their surrounding nature that must be experienced and respected [20]. Unfortunately, little regard for ecological embeddedness in urban development has separated the individual from the locality, and the built environment from nature [21-23]. Therefore, it is only through respect for nature that, amongst other things, healthy and place-based habitats can be re-formulated [24,25].

The present study aims to analyze the environmental sustainability challenges of CNTs currently ongoing in Asia and Africa and suggest some urban planning guidelines that can help mitigate them. There is considerable literature on CNTs in Africa [4-16] and Asia [26-42]. In Africa, Watson [12] analyzed the urban visions and development plans of CNTs in sub-Sahara and criticize them for leading to evicting and relocating vulnerable poor people. Cote-Roy and Moser [4] investigated the roles and interests of interconnected actors that promote the creation of CNTs in Africa. They found that states, elites, and multinational corporations promote this urban development model via modernity/progress narratives and the right to development. Keeton and Nijhuis [7] assessed the physical organization of CNTs in Africa and reported that because they have been designed based on foreign models they are likely to exacerbate both spatial and ecological challenges such as urban sprawl, residential exclusion, reliance on private transport, lack of high-quality public space, and flooding. Abubakar and Doan [11] assessed the efficacy of building CNTs as an urbanization strategy in Africa and found that the projects focus less on meeting present-day urban challenges such as informality, socioeconomic segregation, and urban sustainability. Van Noorloos and Kloosterboer [15] examined the actual and anticipated implications of some CNTs in Africa and contend that they are "unsuitable for solving Africa's urban problems, and at worst they will increase expulsions and enclosures of the poor, public funding injustice and socio-spatial segregation and fragmentation" (p. 1223). Other similar studies on CNTs in Africa center on decentralization [8], spatial and social inequality [13,14], and governance [16].

In Asia, several studies on CNTs have also been conducted. In China, Song et al. [26] studied 42 CNTs around four major cities: 16 around Guangzhou, 10 near Shenzhen, 10 around Foshan, and 6 near Zhuhai. The authors found that CNTs that emphasize physical and economic growth are less likely to improve the quality of the built environment and sustainable development. Ye and Van Nes [27] also examined the spatial flaws of some CNTs in China and found that due to low building density and mixed land uses they lack booming street life and a variety of social activities compared to existing older towns. Another study by Governa et al. [6] focuses on the spatial features of CNTs in China and their roles in the scaling-up of the regional urbanization process. In Indonesia, Firman [28] studied Jakarta's satellite new town, established mainly to fulfill the exclusive lifestyle and security needs of 
the elite, and found that its exclusive residential areas reinforce spatial and income-based segregation. Similar studies on CNTs in Asia include the extent to which Salt Lake new town (India) affects disaster risks [29] as well as the lack of public transportation in Singapore's CNTs [30], urban management challenges in Iranian CNTs [31,32], and the role of CNTs in decongesting Cairo [33].

It is evident from the review of the literature above that studies on CNTs in both Asia and Africa disproportionately concentrate on their social inequality and governance challenges, but with limited focus on environmental sustainability. The present study, therefore, fills this knowledge gap by analyzing the environmental sustainability challenges of these CNTs. Also, this study is the first to utilize lessons from the ecological wisdom of traditional settlements to suggest urban sustainability principles that can help mitigate the sustainability challenges of CNTs in these regions.

To some, the past might look too gloomy to envisage a better future; one might think that the romanticized view of ecological wisdom of traditional settlements has limited modern applicability and cannot help us much [43]. However, the literature offers many instances where they have succeeded as sustainable settlements for centuries [44,45], and that it is difficult to make the same claim for the current highly industrialized and consumption-oriented societies with a proven record of irreversible damage to the environment $[46,47]$. The ecological wisdom of past civilizations embedded people in their place, transforming them into a reservoir of socio-ecological knowledge that not only benefitted their time, but also enabled them to become agents of knowledge transfer to the next generations [48]. This wisdom can enrich our experience of the natural and social sciences. We have seen the exploitation of humans and the environment at the hands of the "privileged" elite. The industrial revolution has increased the realization in the masses about their relationship with the employer, work, and environment. This has given rise to ideas about how humans should live in tune with their aspirations and ecological demands of the planet. With such ecological wisdom, it appears that today we are better equipped to envisage a more humane and livable world for all. Oshima [47] likens the lessons from the past to worthy and unrealized dreams that only the present can fulfill. Thus, the ecologically embedded practices of traditional settlements can provide many valuable lessons for CNTs.

Traditional settlements were able to healthfully sustain themselves for multiple generations living harmoniously with nature, not causing adverse impacts to the society and the environment, and still offering the benefits of urbanism [48,49]. For instance, Momete [50] argues that sustainability and ecological wisdom in the past harmoniously coexist with human activity with the ability of the ecosystem to cope. Wah [51] underscores the ancient knowledge of Feng Shui (Chinese ecological wisdom) in creating spaces for people that even today increases satisfaction, happiness, productivity, and work-environment quality. Smith [34] writes that archaeological findings on ancient cities can inform us about better ways of dealing with contemporary urban challenges like sprawl, squatters, and sustainability. Dhingra and Chattopadhyay [52] opine that to attain a sustainable built environment, the experience of society is as important as socioeconomic and environmental factors. This is particularly true of traditional societies where there are no end-users, but users over time as the natural ecological cycles of a locale intertwin with all human activities. Costanza et al. [24] explain that human interactions with the environment create a complex network of ecological relationships and multidirectional links in time and space so that future generations are impacted by the decisions made by previous civilizations. To better the present and prepare a sustainable future, one can go back to the past to learn from human settlements and their response to climate, and the changing attitudes of humans over time $[53,54]$. Given the successes of traditional settlements, many scholars strongly suggest that there are important lessons for modernist cities to learn.

This article, therefore, discusses how the ecological wisdom behind some traditional settlements in Asia and Africa can help foster environmental sustainability in CNTs, most of which are still on the drawing board. The paper is organized into six sections. Section 2 describes the research methodology and Section 3 analyzes key urban sustainability challenges faced by CNTs in Asia and Africa. Section 4 discusses how the architecture, urban form, and green infrastructure of traditional settlements present excellent cases of ecological wisdom that can help achieve more sustainable built 
environments. Section 5 discusses and recommends some urban planning principles for CNT projects in Asia and Africa. Section 6 concludes the paper.

\section{Methodology}

The present study adopts desktop research methodology consisting of three iterative steps: the problem overview, literature sourcing, and analysis of the findings, as employed in prior studies because of its popularity due to the vast amount of information available online [12,55]. The problem overview step focused on identifying the main objective of this study: analyzing the environmental sustainability challenges of new town projects currently ongoing in Asia and Africa and recommending some lessons from the ecological wisdom of traditional settlements in these regions that can help mitigate the challenges. The justification for selecting the study area shown in Figure 1 is that Asia and Africa are currently the hubs of global urbanization because of their low urbanization levels of $50 \%$ and $43 \%$, respectively, while North America, Europe, and South America have already attained urbanization rates of at least 85\% [3]. From 2015 to 2030, the urban population worldwide is expected to increase by about 2.5 billion people, $90 \%$ of them from Asia and Africa. The private developers of the new towns are also investing in these regions more than anywhere else in the world because of the demand for new town projects resulting from economic prosperity and the rising middle class [Watson, 2014]. The rationale for selecting the traditional settlements as examples is that (i) they are located within the same region as the CNTs and their culture and society display sustainability characteristics, (ii) they show signs of urbanism, and (iii) they are based on the ecological understanding of their inhabitants.

During the literature sourcing step, Google Scholar, Scopus, and Web of Science as comprehensive search engines were used to identify and collect relevant academic and grey literature such as published articles, books, and reports. Other secondary sources such as urban plans and statistics were collected from the websites of public agencies and international development organizations. The literature was identified using search terms such as "new towns," "traditional settlements," "ecological wisdom," "environmental sustainability," "sustainable cities and architecture," "urban form," "urban sprawl," "housing," and "green infrastructure." The collected resources were then organized according to traditional settlements and CNTs in Asia and Africa. The last step involved systematically analyzing each resource to develop themes according to urban sustainability challenges and ecological wisdom. Then a comparison was made between urban sustainability principles related to architecture, urban form, and green infrastructure applied in traditional settlements versus those in new towns. Then findings were then harmonized, synthesized, and summarized in a tabular form. Finally, some urban planning guidelines are recommended for the ongoing new town projects. 


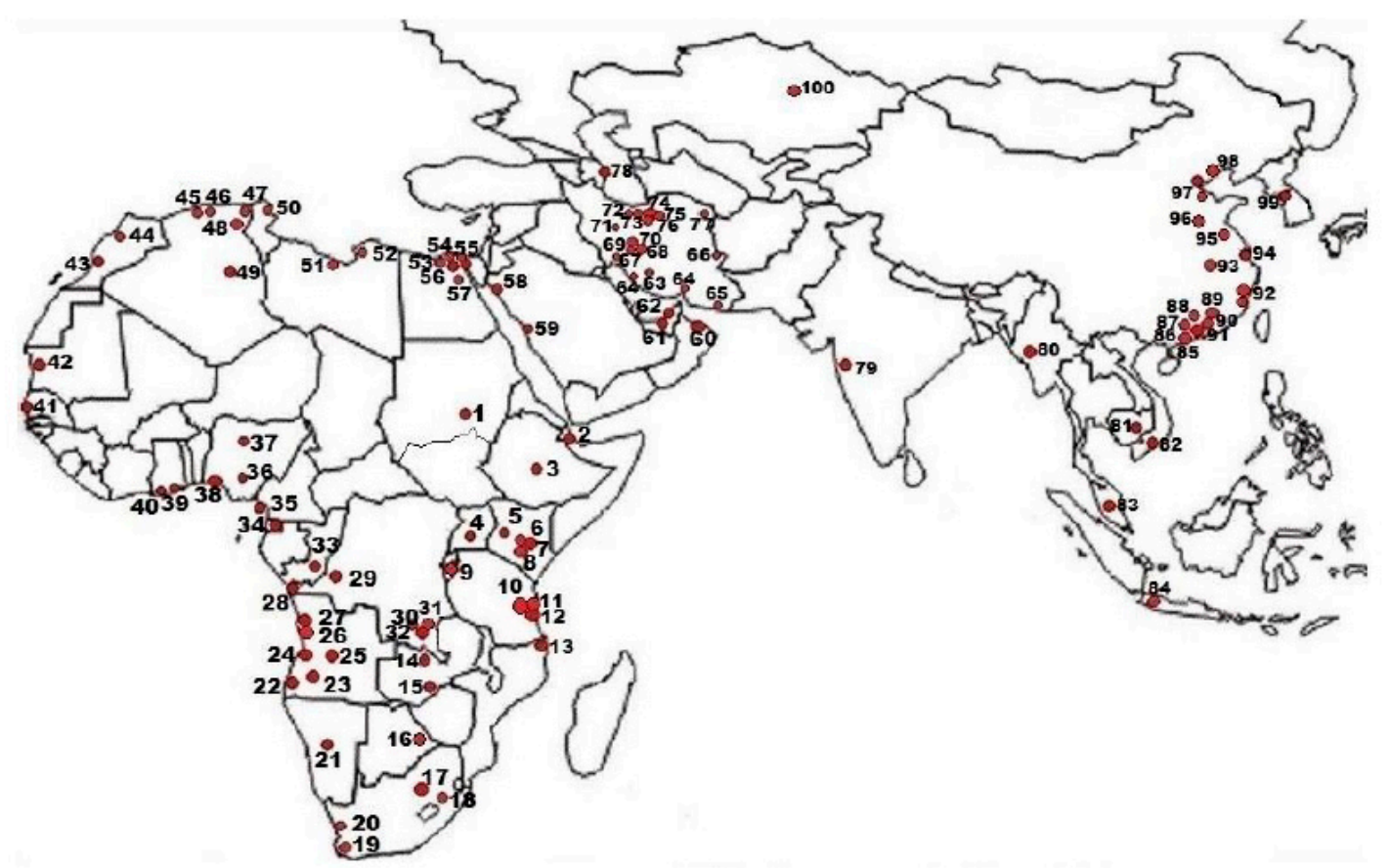

100 Contemporary new towns in Africa and Asia

\begin{tabular}{|c|c|}
\hline $\begin{array}{l}\text { Africa } \\
{[4,12]}\end{array}$ & $\begin{array}{l}\text { 1. Al Mogran (Sudan); 2. Al Noor (Djibouti); 3. Huangjin (Ethiopia); 4. Kukungulu (Uganda); 5-8. Konza, } \\
\text { Tatu City, Machakos, and Anboseli (Kenya); 9. Kigali new town (Rwanda); 10-12. Kigamboni, Safari, \& } \\
\text { Kibada (Tanzania); 13. Palma (Mozambique); 14-15. Kalumbila, Roma Park (Zambia); 16. Selebi (Botswana); } \\
\text { 17-20. Cradle, Lotus Park, Modderfontein, \& Waterfall (South Africa); 21. Arandis (Namibia); 22-27. } \\
\text { Lossambo, Moxico, Bie, Capari, Cacuaco, \& Kilamba (Angola); 28-32. Cabinda, Kiswishi, Luano, } \\
\text { Geniland, \& La Cite' du Fleuve (DRC); 33. Kintele (Kongo); 34. Oyala (Equatorial Guinea); 35. Kribi } \\
\text { (Cameroun); 36-38. Anam City, Kaduna Millennium City, \& Eko Atlantic (Nigeria); 39-40. Appolonia, } \\
\text { Hope City (Ghana); 41. Diamniadio (Senegal); 42. Cansalo (Mauritania); 43. King Mohammed VI Green } \\
\text { City (Morocco); 44. Zenata (Morocco); 45-49. Bouinan, Boughezou, Bourouag, Draa Errich, E1 Mmenea, } \\
\text { \& Hassi (Algeria); 50. Tunisia Economic City; 51-52. Ras Lanuf, (Libya); 53-57. Sadat, Sheikh Zayed, } \\
\text { Shuruq, Madinaty, New Fayoum (Egypt). }\end{array}$ \\
\hline $\begin{array}{c}\text { Asia } \\
{[5,26,} \\
32]\end{array}$ & $\begin{array}{l}\text { 58-59. Neom, King Abdullah Economic City (Saudi Arabia); 60. The Blue City (Oman), 61-62. Masdar } \\
\text { City, Saadiyat Island (UAE); 63-77. Parand, Hashtgerd, Pardis, Andisheh, Latiyan, Majlesi, Baharestan, } \\
\text { Fauladshah, Sahand, Sadra, Golbahar, Binalud, Alishahr, Mohajeran, Alavi, Ramin, \& Ramshar (Iran); } \\
\text { 78. Zira Island (Azerbaijan), 79. Magarpatta (India); 80. Naypyidaw (Myanmar); 81. CamKo (Cambodia); } \\
\text { 82. Binh Duong (Vietnam); 83. Cyberjaya (Malaysia); 84. Bumi Serpong Damai (Indonesia); 85. Tin Shui } \\
\text { Wai (Hong Kong); 85. Shenzhen, 86-98. Zhujiang, Haizhu Ecological City, Tianhe, Huadi, Shenzhen, } \\
\text { Zhangcha, Sanshan, Binjiang, Dayun, Chanxi, Beijiao, Sanshui, Pingshan, Baiyun, Songjiang New City, } \\
\text { \& Tianjin Eco-city (China); 99. New Songdo City (South Korea); 100. Astana (Kazakhstan). }\end{array}$ \\
\hline
\end{tabular}

Figure 1. Locations of notable 100 contemporary new towns in Africa and Asia (compiled by the authors).

\section{Environmental Sustainability Challenges of CNTs in Africa and Asia}

A new town can be defined as a comprehensively planned and self-contained urban development on a greenfield site consisting of land uses divided into "mono-functional zones" [11]. In the Global South, the first generations of new towns emerged during colonialism when new districts were established as administrative and economic centers for the colonial establishment. The second generations are post-colonial new towns such as Abuja, Islamabad, and Dodoma, established around 1960-1980 as the new capitals of independent countries. The third generation consists of CNTs (the focus of the present study) that arose within the last two decades as self-contained satellite towns, towns/districts within or on the edge of booming cities. The CNTs are predominantly in Africa and Asia (Figure 1) developed mainly through partnerships between states and international real estate developers to decongest large cities, stimulate economic growth, and provide the elites with modern communities. 
These CNTs mainly accommodate the rich and emerging middle class, and provide shopping malls, office blocks, private hospitals, schools, recreational facilities, and other amenities [11]. In Africa, Keeton and Nijhuis [7] estimate that by 2030 about 77 million people, or 10\% of Africa's urbanites, could be living in CNTs if their 2018 targets are met. In Asia, China alone has an ambitious plan to design and built 400 new towns by the year 2020 [6]. This will undoubtedly reduce the pressure on the already overwhelmed housing, infrastructure, and basic services in existing cities. As of 2015, at least two-thirds of Africa's urbanities were living in slums without safe and adequate housing and basic services [43]. However, apart from the problems of social and physical exclusion reported in the literature, there are several sustainability challenges associated with CNTs in Africa and Asia.

The CNTs are built based on the modernist planning model, using grand master plans designed by experts and based on a rational, comprehensive, and centralized approach [8]. "To avoid the problem of dealing with decay in existing cities, vacant land provides modernist planners with a chance to regulate the size, structure, and development of a new town, to break with tradition and initiate social change" [11] (p. 549). However, the employed modernist model discourages native designs, knowledge, and construction materials, thus leading to what Moser [18] (p. 33) termed "a visual hierarchy that positions global corporate culture as the future and the local and indigenous as the backward past."

In Africa, CNTs have been criticized for being "functionalist Chinese grids" and "American gated communities" [7] (p. 218) because they are centralized solutions using foreign blueprints and exclusionary viewpoints imposed by international conglomerates of property developers on local communities with little regard for context, indigenous knowledge and values, public involvement, quality of social life, or environmental sustainability, as many of them are being built on an important ecological resource [11]. The modernist architecture dominates the limelight of these CNTs. Spectacular high-rise and iconic Western designs are preferred because they represent the ambition of the elites to project the image of the new towns using modern, magnificent, and dignified buildings (Figure 2). As such, many houses are empty because they are unaffordable to even middle-income citizens, resulting in "ghost towns" and "empty cities" such as Kilamba new town in Angola [7].

Regarding urban form, there is an emphasis on creating a new, inflexible form with top-down and rigid zonal divisions rather than working with the existing one through incremental modification (Figure 3). Likewise, land use is monofunctional and the ecological sustainability principles of compact, mixed, and low-carbon development; conserving the existing natural greenspaces; and focusing on the potential climate change threats are neglected, while environmental impacts assessment is barely conducted [16]. Little attention is paid to the social foundations of urban planning and design because gated communities could intensify social exclusion and erode the public realm due to privatized "public" spaces lacking interconnection with socioeconomic systems, including the interrelationship between poor workers and the elites [13,44]. Similarly, the designs of CNTs are likely to increase urban sprawl and reliance on car transportation and discourage walkability [9]. For example, Cradle and Waterfall new towns (South Africa) are characterized by "automobile-dependent horizontal sprawl" and "environmentally destructive land speculation" [10]. Other challenges such as hazard risks associated with CNTs developed on fragile and low-lying coastal areas are often not addressed by several projects. For example, there is a risk of flooding in Eko Atlantic City (Nigeria), which is located on land reclaimed from the Atlantic Ocean [56]. Similarly, the new town of Modderfontein in South Africa is being developed on a nature reserve site inhabited by different animal and plant species that is used for recreation and nature trails, thus undermining conservation efforts and worsening ecological problems [13]. In Kilamba (Angola), the existing droughts, frequent floods, and solid waste management are neglected issues [7]. The Cradle and Waterfall new towns in South Africa have been described as low-density development with poorly planned landscapes focusing mostly on glamour and luxury [10]. 

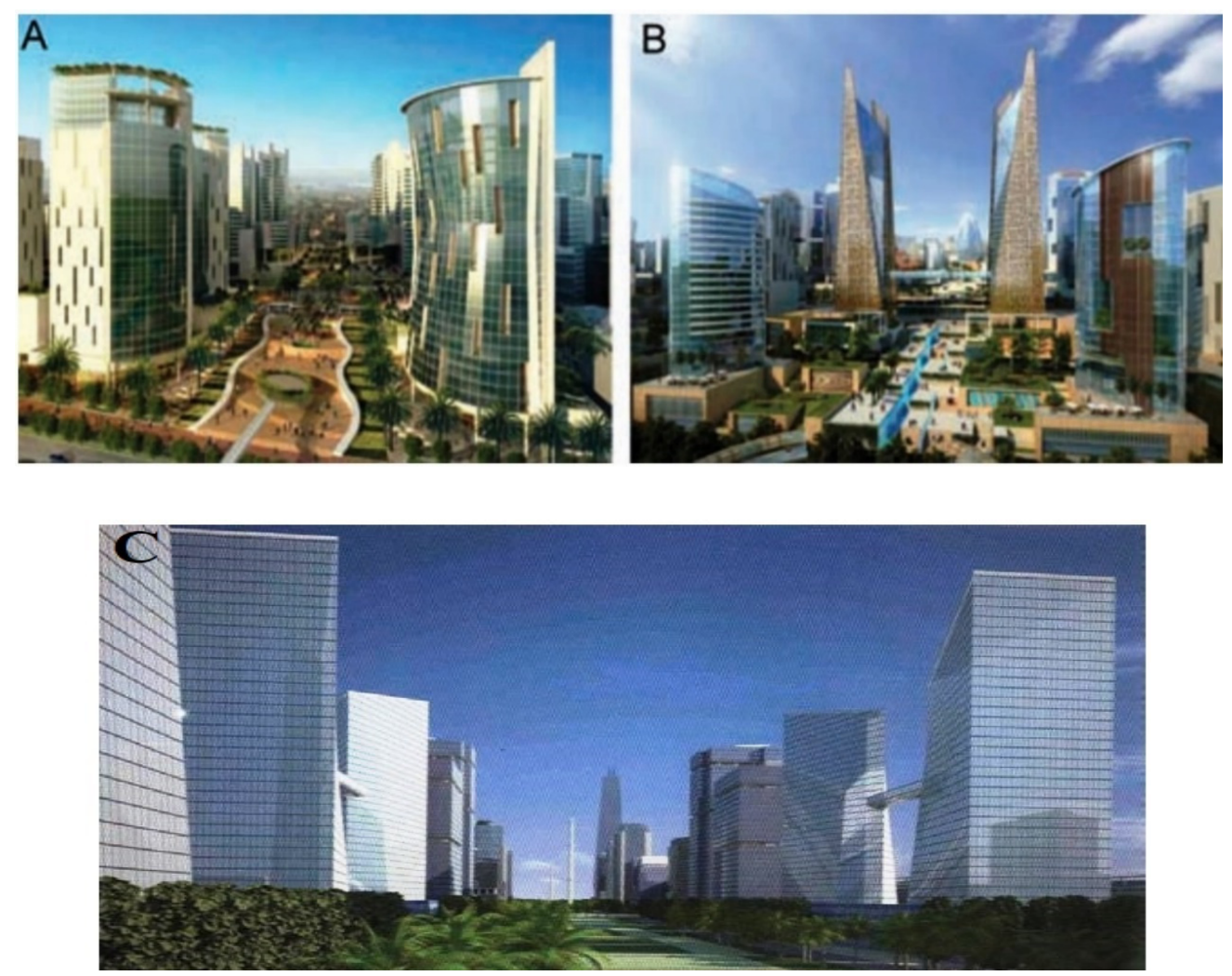

Figure 2. Examples of architectural designs in CNTs in Africa: (A,B) Kigali new town and (C) Kigomboni city [12] (p. 218-221).
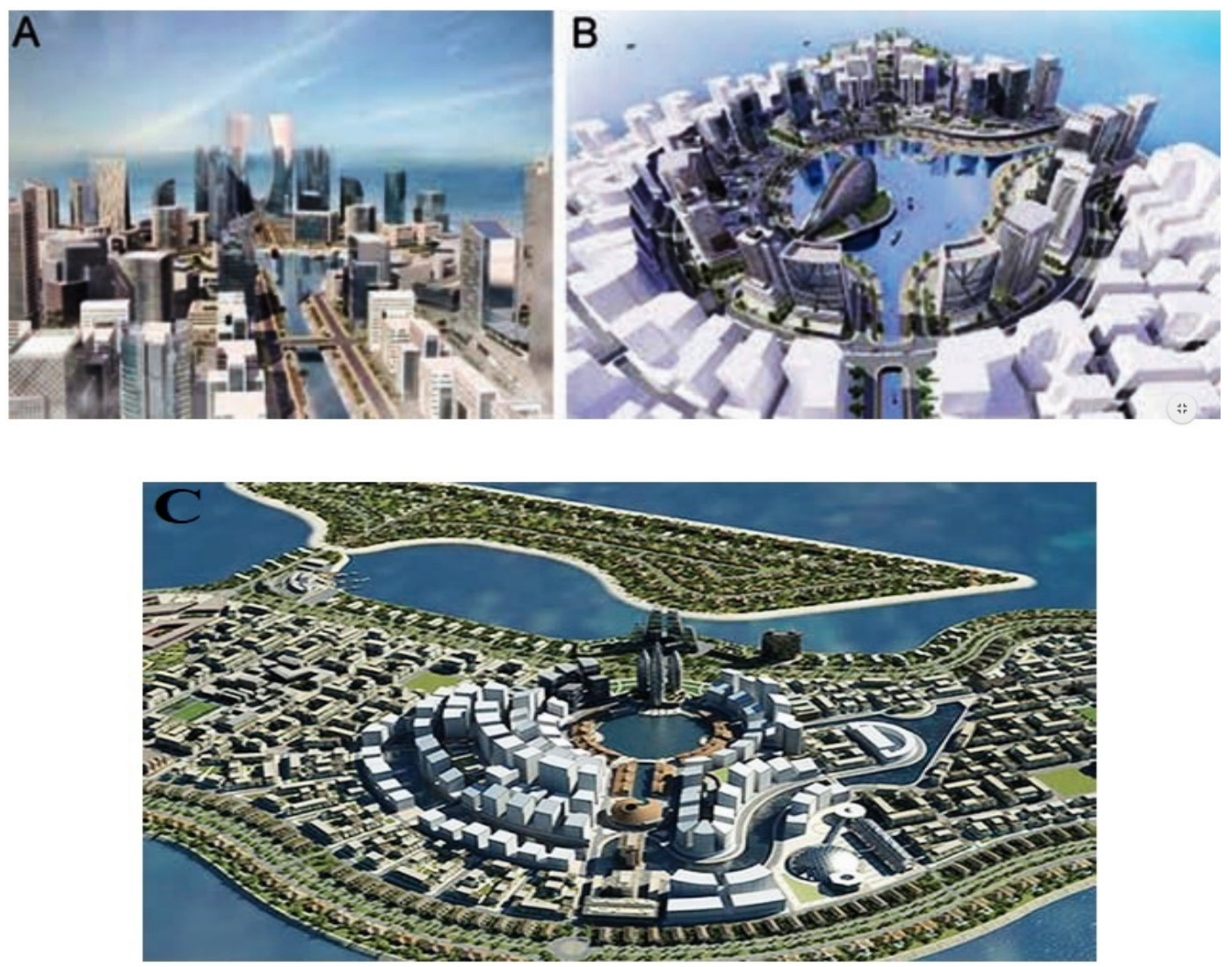

Figure 3. Examples of urban form in CNTs in Africa: (A,B) Eko Atlantic City and (C) Kinshasa: Cité le Fleuve [12] (p. 223). 
In Asia, despite the use of the "eco-city" slogan by promotors, Keeton [5] discovered that the eco-friendly strategies in many CNTs are "nothing more than greenwashing," as environmental sustainability does not form a core element of their urban design concepts. First, Western architectural forms that are divorced from indigenous materials, knowledge, and values are adopted [18,42]. There is also the likelihood of worsening socio-spatial segregation through gated communities, and capsulization. For example, Firman [28] reported the existence of polarized and exclusive pockets of elite residential areas in Jakarta new town.

Second, the urban forms of several CNTs are based on a "one-size-fits-all" approach to urbanism that discourages diversity and negates the peculiarities of the locale [26,28,32]. They are also seen as environmentally deterministic, promoting urban sprawl and overreliance on cars, thereby increasing air pollution. In Beijing, the CNTs have little respect for the nature and geography of the locale and are less self-sustaining [Cai et al., 2020]. There is no provision for public transportation, bicycling, or pedestrian pathways in the master plan of Sheikh Zayed City [7]. Lau [30] also reported spatial mismatch due to work-home remoteness because office developments are inadequately linked with the public transport network in Singapore's CNTs. According to Song et al. [26], Huadi ecological city in China has nothing to do with its label because of disregard for local conditions. In Tianjin Eco-city (China), "pollution-spewing industries" are built close to residential and office developments. In Lake City (on the edge of Kolkata, India), disaster risk in poor neighborhoods is elevated because of higher exposure to natural hazards, poor or non-existent infrastructure, low-quality housing materials, and poor service delivery [29].

Regarding green infrastructure, in several CNTs, urban green spaces such as golf courses and lawns that need extensive maintenance are provided, which become a burden on the cities. For example, green areas within gated neighborhoods in Sheikh Zayed City (Egypt) are immensely irrigated using water piped from the Nile or supplied in tankers during scarcities. Kwak et al. [34] reported that in many Korean CNTs, the lack of blue-green infrastructure significantly aggravates the urban heat island (UHI) effect. Other scholars found poor configuration, unbalanced distribution, and less integration of green infrastructure in the CNTs $[27,29,37]$. Keeton [5] (p. 34) concludes that CNTs in Asia look "so shamelessly elitist, so brazenly commercial, so shockingly superficial." This section has shown that there are several environmental sustainability challenges in these CNTs. Given that the development of most CNTs is in the pipeline or at the planning stage, the observed challenges can be minimized by learning from the ecological wisdom and embeddedness of traditional settlements.

\section{Ecological Wisdom of Traditional Settlements for Achieving a Sustainable Built Environment}

Ecological embeddedness refers to physically living within the ecosystem and identifying with it while adhering to principles of ecological "respect, reciprocity, and caretaking" [57]. These three key attributes are the hallmark of traditional settlements that defines their inhabitants and their existence, and their interaction with their habitat. Up until the Industrial Revolution, people lived, worked, traded, and gardened in the same place, which gave rise to an increased understanding of ecological context. Their work and social lives were intertwined with the surrounding nature. This section, therefore, discusses how the architecture, urban form, and green infrastructure of traditional settlements present an excellent case of ecological wisdom and embeddedness that can provide valuable lessons for CNTs to foster environmental sustainability.

\subsection{Architecture}

Western styles of architecture and building standards are adopted in designing the CNTs because elites in the host countries aspire to portray the image of becoming modern and "catching up with the West" [10]. There is little appreciation of local climatic conditions, building materials, or construction techniques specific and suitable to the locality [11]. Yet one of the hallmarks of vernacular architecture of traditional settlements is the embeddedness of sustainability via a deep understanding of the local climate and region, informed by an in-depth observation and experience of its inhabitants, which offers 
guidance to more sustainable architecture and urban fabric planning [Sharifi]. Local climate determines the architectural form, identity, and functional effectiveness; local building materials make the building low cost; and construction is quick as centuries-old experience is revered, adopted by the current generation, and passed to future generations [58-60].

For example, Widodo [54] writes that the vernacular architecture of Southeast Asia reflects the region's tropical climate such that the material and construction techniques withstand high humidity and rainfall: traditional wisdom passed down through centuries of accumulated understanding of the context. Using locally available bamboo in buildings ensures cheaper construction, stronger structures, longer-lasting buildings, effective ventilation, regional identity, and a sense of place. According to Guo and Wang [61], the architecture of the Zhang Jiata village (China) conforms to the mountainous landscape and terrain, and by doing so, it achieves form integrity and organic order. The buildings designed in such a fashion are well ventilated, have more sunlight, and provide a better visual environment.

In Japanese traditional settlements, vernacular architecture helped houses withstand natural disasters such as earthquakes, floods, fires, and typhoons [62]. The super-structure was placed on the building foundations without any attachments, which allowed for free movement of foundations without sending the quake vibration upward to the structure. The same principle was applied in the construction of five-story pagodas that survived many earthquakes. Here, only the main central column was loosely tied to the floor plates, which receded in size as the pagoda gained height. The other columns on the floor only held the roof up. The bracing beams on top of these columns did not meet with the central column. In the event of an earthquake, the structural components of the pagoda moved and the friction that arose because of this movement worked as an "earthquake damper," reducing the effect of the earthquake vibrations. Loosely tied and allowed-to-open exit doors were provided in large buildings that only opened outwards because of the vibration caused by the earthquake. This helped a great deal in evacuating the building.

Okubo [62] further writes that given their locations, Japanese towns have always been subjected to high rainfall and floods. Since all houses used wood as the main construction material given its local availability, the houses were susceptible to moisture and degradation. To take care of this, mud tiles and mud plaster were used to fight moisture and protect the wood from degenerating. Typhoons and strong winds were countered by coral stone walls built around the houses. The ground floors of the houses in certain towns were recessed into the ground such that the roof of the house was at street level. This reduces the effect of the speedy winds, preventing the roofs from being blown off by them. Additionally, the wooden roofs were structurally detached from the main structure either by placing them onto a different construction material or placing them on wooden columns constructed in two parts. In case of fire, the roof could easily be taken off and the rest of the structure demolished to extinguish the fire.

Bayoumi [63] describes the residents of traditional settlements of ancient Nubia in the Aswan region (Egypt) as great architects who mastered the art of making buildings that are environmentally and socially responsive. The chief building material, mudbrick for walls and vault roofs, is available locally with little environmental stress because wood is not required. The height of the roof and the thickness of the walls is carefully worked out so that the passive ventilation system is effective. The houses have courtyards that keep houses cool in summer, whereas the grouping of houses is closely knit and in a winding fashion that allows a swift flow of wind in summer and causes barriers to the cool winds in winter.

Dhingra and Chattopadhyay [52] present an interesting case study of traditional houses in Riyadh, Saudi Arabia. The authors write that the weather conditions of Riyad are well reflected in the traditional courtyard houses, with passive ventilation through mulgufs (wind-towers) where the hot wind escapes the interiors, letting in the cool wind. In winter, the same courtyard becomes an outdoor place for most activities. The wear and tear of the buildings over time can be easily taken care of, as clay is the chief sustainable construction material and the people have the knowledge of how best to use it for maximum benefits. The clay keeps the houses cool in summer and warm in winter. The buildings are 
grouped closely for mutual shading, creating a microclimate. The town core has a multi-functional land-use pattern that can be accessed through different corridors with souqs (traditional bazaars). This gave rise to compact development, high density, and walkability. Minimum impervious materials used in the walkways ensures rainwater absorption and room for growing local trees.

Shaowen and Hanqi [64] studied the architecture of traditional houses in south Yunnan, China. The houses show adaptability to the local conditions using local construction materials such as rammed earth, bamboos, straws, and wood that pose little harm to the environment. These materials not only save costs but are also sustainable. For example, the rammed earth can be reused, and trees can be replanted and sustainably harvested. The construction techniques are also environmentally sustainable because the wall thickness and roofing system depend on the regional climate. Because of long, hot summers, no winter, and less rainfall in some regions, a rammed clay house is best suited and adopted. Villages on the hillsides are warm during the winter and cool in summers with heavy rain. In this region, a two-way or four-way thatch or titled roof has been adopted, with rammed clay walls that ensure effective drainage. If in a particular region there are mosquitos and snakes due to high humidity and rainfall, communities raise stitched houses to protect themselves. This centuries-old wisdom regarding the sustainability of the built environment is transmitted from one generation to the next.

\subsection{Urban Form}

Urban form is the arrangement of the functional elements of a city such as buildings, roads, green spaces, and plots. The configuration of such elements not only provides the structure of the city and transforms it, but also impacts urban sustainability by directly affecting both outdoor and indoor climates $[65,66]$. Cities are planned with a variety of styles, including modular orthogonal gridiron, compact, eco-city, and mixed uses [67]. Urban forms have specific functional and aesthetic variations, whether organic or planned, or organic or irregular. The layout of an ancient city can be informal, but it often displays conscious coordination between buildings and spaces and standardization of the constituent urban forms. The urban form of traditional settlements fosters a diversity of activities and considerable face-to-face interaction arising from mixed activities, shared interests, and common use of facilities [68]. Functional urban zones are integrated into the public realm, such as urban courts, arenas, accessible marketplaces, and landscaped spaces that promote inclusion and increase social cohesion [69]. Such neighborhoods promote a strong sense of community and allow a good observation of the effects of human activity on a lower scale.

In traditional Iranian cities, Sharifi and Murayama [70] revealed that social sustainability was ensured through various thoughtful design decisions that ensured physical coherence and connectivity between all sections of the city working as one unit. The traditional bazaar (bazzarche) formed the main spine connecting the central square (maidan) and the mosque and terminating at the residential quarters (mahalleh). The residential quarters, on the other hand, had their maidans, a smaller bazaar, and public baths (hammams), fulfilling the daily needs of the residents while encouraging the gathering of people from all walks of life, which resulted in an awareness of different classes and social cohesion. Given this urban fabric, form, and connectivity, the people frequently interacted with one another. Climatic considerations were also followed in designing the streets and the close placement of the zones and building blocks that not only protected the users from the harsh weather but also encouraged personal encounters among residents. In other words, the compression of space, tight knitting of the streets, and the absence of automobiles gave rise to a walkable environment that in turn made social interactions possible and safe. In Kampong (Malaysia), the houses were arranged in clusters and patio groups that allowed for both bottom-up self-organization and top-down administration [54]. The pooling of risk in these settlements is also noticeable, and promoted a sense of trust, reciprocity, respect, solidarity, and reputation. These clusters and patio groups show the same characteristics as those of an urban neighborhood. In such wise, these settlements transcend the dichotomy of rural versus urban. 
King [71] relates a similar ecological embeddedness of traditional agrarian communities in Southeast Asia. The ancient settlements minimized the chance of ecological degradation happening due to human activities through communal ownership and management of land and natural resources, with the authority to grant use rights to individuals and groups. The violation of granted rights was punishable. The sense of community was so strong that the idea of increased private wealth was alien. Given the fact that all things and phenomena are connected, selfish behavior cannot persist in a community and still go unnoticed by the existing social and environmental structure. Different rights to the same common resource puts "more eyes" on the resource being used, which is a strong argument in favor of having a common resource pool in the community and valuing collective over individual action and well-being. The sense of community is further made strong by providing immediate feedback and conservation, which tackles the issue of resource speculation and unsustainable practices.

The ecological wisdom evident in the planning of Huazhai historical village in Taiwan is quite inspiring, according to Chu et al. [72]. The main principles here were that the settlement was surrounded by the mountains and close to the water body to ensure sustainability for the residents. However, the location also came with the challenge of prevailing winds and monsoon precipitation, as these surpassed the wind speed limits considered comfortable. Therefore, the planning considered the climate while locating and orienting buildings such that the winter monsoon winds were blocked by the hills located on the north side of the village. The longer sides of the houses also faced the winter winds at an angle of 112.5 degrees, with little to no openings. This not only reduced the wind speed and exposure but also made the courtyards inside the houses comfortable to occupy because of large interior windows providing light and ventilation. There was no physical barrier for the summer winds entering the village. However, the angle of the main street was 22.5 degrees to the prevailing wind. This efficiently affected ventilation and slowed down the wind that exceeded the minimum value and increased outdoor comfort. Zheng et al. [73] reported another ecological wisdom about Hongcun village in China. This preindustrial settlement is a good case of positive human-nature interaction that ensured better quality of life with minimal adverse environmental impact. Its strategic placement between the mountains and the lake blocked cold winds in the winter and allowed the cool moist winds to enter the built environment in summer thanks to the well-planned open spaces and streets, and their orientations. The land-use pattern and building height allowed for maximum view of the natural environment containing green spaces, water, and the sky. This created an esthetically appealing urban form and an effectively positive local microclimate.

In Hani traditional villages (China), live human interaction is important for the collection of neighborhoods and districts to function [64]. However, other ecological and social understandings also play an important role when selecting certain land for inhabiting and laying outhouses, streets, open spaces, and production areas and landscapes. For instance, given their altitude of 1400-1800 m, the villages are consciously built on fairly open land and have gentle slopes to maximize access to the sun, and each village has residences, agricultural fields, a forest reserve, and access to the river [64]. This forest-village-cropland-water continuum ensures harmony with the local ecology and avoids inequality where more people occupy less land and fewer people occupy more land. The same characteristics of choosing the land for housing are found in Western Beijing's ancient settlements [74].

Dhingra and Chattopadhyay [52] write that the walled city of Alwar in Rajasthan is another example that shows the sustainable form of traditional settlements. Here, the mixed land-use neighborhoods were tightly knit, giving rise to compact development. About $29 \%$ of the population worked from home, whereas $51 \%$ was employed in the center, which, given the city's compactness, was reachable on foot. House orientation avoided direct sunlight, courtyard planning kept the houses cool, rainwater was collected in wells for summer use, and the amount of impervious material was minimum, except for the main arterial roads. Another example of sustainable urban form is the ancient city of Ur, where its organic patterns display a planning concept to meet cultural, climatic, and defensive needs [75]. The districts were dense and enclosed, while the streets were narrow and winding to mitigate dust and windstorms, provide shade, and keep houses cool in summer. 
In Java (Indonesia), traditional cities comprised an alun-alun (open square), a kraton (royal palace), worship places, and a market square. The outskirt villages were also considered part of the city through territorial integrity from the city center to the suburb [76]. In China and Sri Lanka, traditional settlements also had places for religious and social functions on spread-out locations, which points towards different zones that performed different occupational activities in addition to agriculture $[77,78]$. Another instance of thoughtful land-use management exists in the villages on the Kanto Plain in Japan. According to Sprague [79], the traditional land-use pattern shows a deliberate concentric arrangement of residences, farms, and woodlands. This land-use pattern considered the topography and ecology of the region as well as which function was possible at which location within a region. As a result of this land-use pattern, communities decided which percentage of area was to be given to which land use so that resource sustainability was ensured.

\subsection{Green Infrastructure}

Green infrastructure is an organized network of natural green areas that provide various ecosystem services including agriculture, recreation, flood barriers, walkability comfort, and reducing urban heat island effect and pollution by increasing air quality [80]. According to $\mathrm{Yu}$ [81], green infrastructure was an inextricable part of traditional settlements where areas dedicated to agriculture and urban greening shaped the built environment and fostered resilience. Barthel and Isendahl [59] write that the idea that urban life is something divorced from rural still occupies modern urban scholarship. In traditional settlements, composite residential compounds and their autonomously managed gardens and neighborhoods, along with their surrounding agricultural land, formed the basic unit of the city. Green infrastructure was connected to the secondary civic-ceremonial functional zones that were in turn linked to the centrally located elite residences and the core complex of the city through causeways.

Talking about the importance of agricultural landscape in traditional settlements, Guttmann-Bond [43] writes that ancient urban agricultural practices were more resilient during unforeseen environmental changes. Urban agriculture relied on different farming techniques that were an appropriate response to the environmental, economic, and political situations. The fact that the agricultural landscape was a part of the built environment is archaeologically evidenced by people living in all kinds of regions, including wetlands and deserts [43]. In Kampong (Malaysia), protecting the forest as green infrastructure and mountains as the sources of freshwater for the inhabitants is among the social rules strictly followed to ensure ecological sustainability [54]. Similarly, the Khasi tribe that lives in Meghalaya state in India also displays significant traditional ecological wisdom [45]. For centuries, the tribe lived completely sustainably and tied to the land and its ecology, consisting of hilly terrain and diverse green spaces that fulfill all the community's needs, including food and medicines. As such, the tribe reveres the ecosystem and forbids any harmful actions. Even removing a fallen leave from the ground and taking it outside of the village without counsel is prohibited.

In Hongcun traditional settlement (China), a high percentage of permeable surface in the form of green spaces ensures a natural flow of stormwater under gravity and its absorption and water conservation [73]. Given this, the water management system can store enough rainwater required for a year. The flowing water in the channels that run alongside the streets is used for multiple human activities. All human and animal waste is composted and returned to the greenspaces as fertilizer [73]. In essence, green infrastructure improves the quality of human life, biodiversity, influences microclimatic conditions, humidity in the soil, and the structure of the vegetation [82], and is key to the environmental sustainability of traditional settlements. However, in CNTs green infrastructure is threatened by urban expansion and unsustainable land-use practices (see Table 1). 
Table 1. Summary of sustainability challenges in CTNs vs. the ecological wisdom of traditional settlements in Asia and Africa.

\begin{tabular}{|c|c|c|}
\hline & $\begin{array}{c}\text { Sustainability Challenges of CNTs in Asia and } \\
\text { Africa }\end{array}$ & $\begin{array}{l}\text { Ecological Wisdom of Revived } \\
\text { Traditional Settlements in Asia and Africa }\end{array}$ \\
\hline Architecture & $\begin{array}{l}\text { - Fanciful Western architecture with little } \\
\text { local relevance [12,15]. } \\
\text { Architecture lacks site-specificity } \\
\text { (copycatting) and existing site conditions } \\
\text { and context are ignored [12,27,28]. } \\
\text { - Costly foreign designs and building } \\
\text { materials requiring high investments for } \\
\text { construction and maintenance lacking } \\
\text { sustainability principles }[5,11,26] . \\
\text { - Over-dependence on energy for } \\
\text { environmental control within } \\
\text { buildings [41,58]. } \\
\text { Forced land eviction (bulldozer approach) } \\
\text { to create space for construction } \\
\text { projects }[4,5,14,16] . \\
\text { Elites are the focus of the housing scheme } \\
\text { rather than low-income social strata [13,32]. }\end{array}$ & $\begin{array}{l}\text { - Local climate determines the } \\
\text { architectural form, identity, and } \\
\text { functional effectiveness [54]. } \\
\text { Architectural form is integrated with } \\
\text { the features of a given terrain and is } \\
\text { strictly contextual [61]. } \\
\text { Resilience to earthquake, fire, } \\
\text { typhoons, and dampness are part of } \\
\text { the architectural form [62]. } \\
\text { Passive ventilation is free of any } \\
\text { energy cost, the height and width } \\
\text { calculations for walls and roofs } \\
\text { depend upon the wind and weather, } \\
\text { and courtyards allow for ventilation } \\
\text { and socializing [52,63]. } \\
\text { Local building materials are cheap and } \\
\text { sustainable, and make the construction } \\
\text { convenient and affordable [64]. }\end{array}$ \\
\hline Urban form & 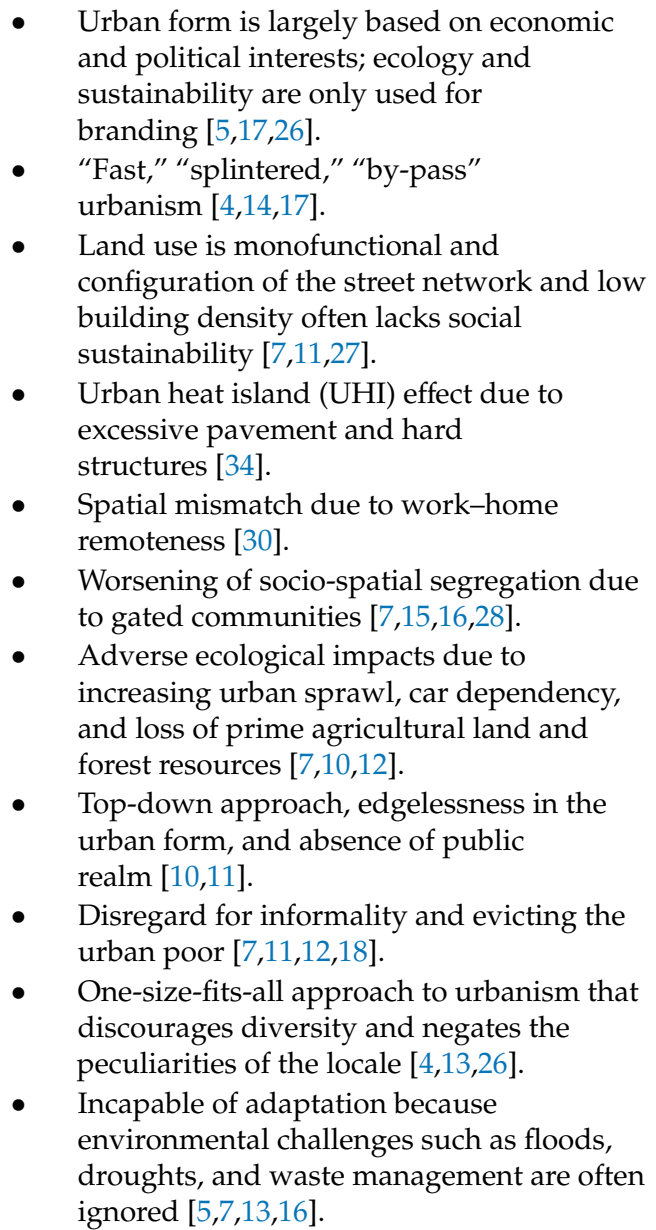 & $\begin{array}{l}\text { - Tightly knit urban form reduces heat } \\
\text { gain and proximity to production and } \\
\text { market areas gives rise to walkability } \\
\text { as well as an urban form that fosters } \\
\text { social sustainability by mingling } \\
\text { people from all walks of life [52,75]. } \\
\text { Organic nature of the urban form } \\
\text { solves problems of the climate and } \\
\text { security [67,68]. } \\
\text { The built environment is oriented to } \\
\text { invite good winds and block bad } \\
\text { winds and sunlight is maximized by } \\
\text { gentle site slopes that give rise to more } \\
\text { views of the natural landscape [72,73]. } \\
\text { The mixed land-use pattern ensures } \\
\text { that settlements are edgeless and } \\
\text { integrate functional urban zones with } \\
\text { the public realm, such as urban courts, } \\
\text { arenas, religious centers, and } \\
\text { accessible marketplaces [69,77,78]. } \\
\text { The urban form fosters harmony } \\
\text { between human activities and the local } \\
\text { ecology and avoids inequality where } \\
\text { more people occupy less land, and } \\
\text { fewer people occupy more } \\
\text { land [64,74]. } \\
\text { Public spaces promote inclusion, } \\
\text { increase social cohesion, and are } \\
\text { multi-functional: religious centers, } \\
\text { spaces for cultural events, and mini } \\
\text { zones for market-related } \\
\text { activities [70,78]. }\end{array}$ \\
\hline
\end{tabular}


Table 1. Cont.

\begin{tabular}{|c|c|c|}
\hline & $\begin{array}{c}\text { Sustainability Challenges of CNTs in Asia and } \\
\text { Africa }\end{array}$ & $\begin{array}{l}\text { Ecological Wisdom of Revived } \\
\text { Traditional Settlements in Asia and Africa }\end{array}$ \\
\hline $\begin{array}{c}\text { Green } \\
\text { Infrastructure }\end{array}$ & $\begin{array}{l}\text { - } \quad \text { Expensive green infrastructure that excludes } \\
\text { the common urbanite }[7,11,16] \text {. } \\
\text { The design and maintenance of green } \\
\text { infrastructure happens outside the local } \\
\text { dictates of ecology, people, and } \\
\text { policy }[4,13,14,18] \text {. } \\
\text { - Poor configuration, unbalanced distribution, } \\
\text { and less integration of green } \\
\text { infrastructure [27,29,37]. } \\
\text { - Urban green spaces such as golf courses and } \\
\text { lawns need extensive maintenance and are a } \\
\text { burden on the city [7]. } \\
\text { Lack of blue-green infrastructure } \\
\text { aggravates the UHI effect [34]. } \\
\text { Monofunctional greenways (landscaped } \\
\text { corridors, bike lanes, pedestrian paths) } \\
\text { exclusively for the elites [30,40]. }\end{array}$ & $\begin{array}{l}\text { Green infrastructure has been an } \\
\text { inextricable part of traditional } \\
\text { settlements [64,81]. } \\
\text { High percentage of green areas and } \\
\text { less impervious surface materials } \\
\text { absorb runoff [52]. } \\
\text { Urban farming as part of green } \\
\text { infrastructure provides food security, } \\
\text { income, and social inclusion and } \\
\text { reduces the UHI effect [71]. } \\
\text { Organic waste is collected and } \\
\text { recycled as fertilizer for landscaped } \\
\text { areas and farms [73]. } \\
\text { Water ponds are multifunctional, } \\
\text { providing socioeconomic, } \\
\text { environmental, and spiritual } \\
\text { benefits [59]. } \\
\text { Existing forests are completely } \\
\text { conserved, maintained, and coopted } \\
\text { into the urban design [45,79]. }\end{array}$ \\
\hline
\end{tabular}

\section{Discussion and Recommendations}

The ecological wisdom of the traditional settlements discussed above and how it shaped the built environment to remain sustainable for many centuries offer the following key lessons for CNTs to improve their environmental sustainability. The following recommendations show how the lessons can be translated and transferred into practice in the design and building of CNTs.

\subsection{Sustainable Architecture and Land-Use Planning}

The architectural designs and land-use management in traditional settlements helped in creating human-environment interactions that gave rise to sustainable settlements. All different elements of the natural environment, including topography, climate, soil, flora, fauna, history, society, and culture, were related to each other and they functioned collaboratively to contribute to a sustainable lifestyle. All human actions took place within the ecological allowances of a given settlement, and the ability to listen to and address the environmental feedback was extremely important. Construction materials were completely reusable and recyclable, and the nature of the materials dictated the construction techniques. As such, instead of importing expensive foreign planning models, building materials, and designs, CNTs should adopt a more sustainable urban development approach benefitting both humans and their environment through physical, psychological, social, and spiritual connectedness of people to their land. In most of Asia and Africa, urban spaces are structured around a flexible form and extended families, which do not fit properly into Western designs [83]. Areas dedicated to various land uses, including housing, commerce, public services, industries, green spaces, water bodies, and fallow lands, should be integrated. Space size and location for these areas should be decided and implemented in a way that ensures a qualitative built environment with fewer adverse impacts. Local construction materials can play a vital role in providing climatically responsive buildings with little environmental and economic stress. Also, resilience should be built into the built environment by developing a land-use scheme that can accommodate various production zones and propose a policy of when and how to use these zones. This can give rise to predictable sustainability in favorable times and resilience in the event of natural disasters [84]. There is a need to also emphasize a walkable environment that increases urban livability due to the simplicity of human activities, the quality of interaction that it imparts, and engagement with the built environment. 


\subsection{Compact Urban Form and Mixed Land Uses}

A compact city with mixed land uses and that is densely populated can help combat urban sprawl, address climate change, and promote environmental sustainability. How dense or spread-out a settlement is would be defined by the area's ecological demands. The traditional settlements discussed above are compact and most activities happened outside; workplaces were in proximity with residential areas; people were well connected, and opportunities abounded for the provision of socio-cultural facilities. Given that most land-use plans of the CNTs are not yet implemented or city building is in its infancy, such plans can be amended to ensure a more compact and mixed urban form. A sustainable city should have a density of at least 150 persons/hectare, as recommended by UN-Habitat [85]. This can help lower environmental pollution and the costs for providing and maintaining infrastructure and basic urban services, as well as improve energy efficiency and better access to public services. Compact development can also support social interaction and promote walkability, thereby creating a vibrant street life, bringing people into public spaces, promoting health, and creating a sense of identity while reducing landscape fragmentation. Adopting a single-use zoning strategy should be discouraged because it every so often leads to environmental problems such as traffic congestion, car dependency, urban sprawl, and declining quality and vitality of cities. Mixing compatible land uses such as homes, shopping centers, and offices can create jobs locally, provide community support, and encourage walkability and bicycling [85].

\subsection{Green Infrastructure and Urban Agriculture}

A greater dependence on understanding how ecosystems sustain humanity is among the main features of the built environment of traditional settlements, even in regions with low rainfall and where sustainable agriculture is thought to be difficult to practice. Green infrastructure has been an inextricable part of traditional settlements with substantial green areas and less impervious surface materials that absorb runoff. Urban agriculture does more than just provide food and ecosystem services for the people; it connects them to the environment and provides them with an identity as a society and culture [86]. Organic waste is collected and recycled as fertilizer for landscaped areas and farms. While forests and agricultural lands are cleared to create a clean slate to build CNTs, the destruction of the natural environment was tantamount to sinning in the reviewed case studies. As such, there is a need to conserve and integrate the existing natural environment into urban design. In addition, given the fact that most daily-life activities took place around a neighborhood, a reasonable walking distance needed to be enough to access different green areas. Given this, temporal knowledge acquired by past generations was highly valuable for the traditional settlements and people, and can play the same role in CNTs.

\section{Conclusions}

High urbanization rates, a demographic surge, a booming middle class, and the aspiration of the state and elites for modernity and progress are the main catalysts for the proliferation of CNTs in Asia and Africa. These CNTs have emerged within the last two decades, and some estimates indicate that more than 100 of them are either at the planning stage or that their construction is in its infancy, which provides an opportunity for critical reflection on their existing challenges and finding ways of mitigating them. This study contributes to this issue by analyzing the environmental sustainability challenges of CNTs in these regions and draws some lessons from ecologically embedded practices of traditional settlements that can help mitigate the challenges. This study found that the architecture of these CNTs consists mostly of fanciful copycatting designs that are based on imported concepts and foreign building materials and overreliance on energy for environmental control within buildings. Regarding the urban form, profit and vision of modernity are preferred over ecological and social considerations. The urban form is largely based on a one-size-fits-all concept consisting of low density, monofunctional land uses, lack of public realm, overreliance on private automobiles, social and physical 
segregation, and inadequate adaptation to environmental risks. Similarly, there are several instances of poor configuration, unbalanced distribution and less integration of green infrastructure, and common urbanites being excluded from access to green spaces.

This paper therefore contends that the ecological wisdom of the traditional settlements discussed above presents opportunities for sustainable urbanism in CNTs in Asia and Africa because land uses are mixed and nature is used to benefit humanity, but not at the cost of damage to the environment and where the result is a harmonious and mutually beneficial co-existence. Rapid urbanization and seemingly unlimited material consumption that has defined human existence and shaped cities for the past century significantly contrast with the ecological embeddedness of the traditional settlements discussed in this paper, where the ecological allowance guides how much and when material gain must take place and how it should affect the built environment. This ecological wisdom can inform the planning and building of CNTs currently thriving in Africa and Asia. Thus, this paper recommends adopting sustainable architecture and land-use planning, compact urban form and mixed land use, and integrated green infrastructure and urban agriculture. These sustainable development practices can help mitigate the identified sustainability challenges of CNTs in Asia and Africa. If sustainably planned and implemented, CNTs have several benefits, such as accommodating urbanization and complementing development.

Author Contributions: Conceptualization, I.R.A., N.A. and A.S.B.; methodology, I.R.A.; formal analysis, I.R.A. and N.A.; investigation, I.R.A., N.A. and A.S.B.; resources, I.R.A., N.A. and A.S.B.; data curation, I.R.A., N.A. and A.S.B.; writing - original draft preparation, I.R.A., N.A. and A.S.B.; writing-review and editing, I.R.A. All authors have read and agreed to the published version of the manuscript.

Funding: This research received no external funding.

Acknowledgments: The authors thank Noel G. Keough David P. Monteyne, Asiya Sadiq Polak, Muhammad Shanjer, and Aysha Agha Shah for commenting on the earlier version of the manuscript. Thanks also to the three anonymous reviewers whose suggestions have improved the quality of the article.

Conflicts of Interest: The authors declare no conflict of interest in the conduct of this study.

\section{References}

1. Seto, K.C.; Güneralp, B.; Hutyra, L.R. Global forecasts of urban expansion to 2030 and direct impacts on biodiversity and carbon pools. Proc. Natl. Acad. Sci. USA 2012, 109, 16083-16088. [CrossRef]

2. United Nations. World Population Prospects 2019: Volume I: Comprehensive Tables; United Nations Department of Economic and Social Affairs: New York, NY, USA, 2019.

3. World Bank. World Development Indicators 2016: Featuring the Sustainable Development Goals. The Highlights; World Bank Group: Washington, DC, USA, 2016.

4. Cote-Roy, L.; Moser, S. Does Africa not deserve shiny new cities? The power of seductive rhetoric around new cities in Africa. Urban Stud. 2019, 56, 2391-2407. [CrossRef]

5. Keeton, R. Rising in the East: Contemporary New Towns in Asia; International New Town Institute: Amsterdam, The Netherlands, 2011.

6. Governa, F.; Sampieri, A. Urbanisation processes and new towns in contemporary China: A critical understanding from a decentred view. Urban Stud. 2020, 57, 366-382. [CrossRef]

7. Keeton, R.; Nijhuis, S. Spatial challenges in contemporary African New Towns and potentials for alternative planning strategies. Int. Plan. Stud. 2019, 24, 218-234. [CrossRef]

8. Abubakar, I.R.; Doan, P.L. New towns in Africa: Modernity and/or Decentralization? In Proceedings of the 53rd African Studies Association Annual Meeting. San Francisco, CA, USA, 18-21 November 2010.

9. Grant, R. Sustainable African urban futures: Stocktaking and critical reflection on proposed urban projects. Am. Behav. Sci. 2015, 59, 294-310. [CrossRef]

10. Herbert, C.W.; Murray, M.J. Building from scratch: New cities, privatized urbanism and the spatial restructuring of Johannesburg after apartheid. Int. J. Urban Reg. Res. 2015, 39, 471-494. [CrossRef]

11. Abubakar, I.R.; Doan, P.L. Building new capital cities in Africa: Lessons for new satellite towns in developing countries. Afr. Stud. 2017, 76, 546-565. [CrossRef]

12. Watson, V. African urban fantasies: Dreams or nightmares? Environ. Urban. 2014, 26, 215-231. [CrossRef] 
13. Brill, F.; Reboredo, R. Failed fantasies in a South African context: The case of Modderfontein, Johannesburg. Urban Forum 2019, 30, 171-189. [CrossRef]

14. Cain, A. African urban fantasies: Past lessons and emerging realities. Environ. Urban. 2014, 26, 561-567. [CrossRef]

15. Van Noorloos, F.; Kloosterboer, M. Africa's new cities: The contested future of urbanisation. Urban Stud. 2018, 55, 1223-1241. [CrossRef] [PubMed]

16. Abubakar, I.R. Governance Challenges in African Urban Fantasies. In Land Issues for Urban Governance in Sub-Saharan Africa; Home, R., Ed.; Springer Nature: Cham, Switzerland, 2021; pp. 155-169.

17. Bhan, G. The real lives of urban fantasies. Environ. Urban. 2014, 26, 232-235. [CrossRef]

18. Moser, S. New cities: Old wine in new bottles? Dialogues Hum. Geogr. 2015, 5, 31-35. [CrossRef]

19. Patten, D.T. The role of ecological wisdom in managing for sustainable interdependent urban and natural ecosystems. Landsc. Urban Plan. 2016, 155, 3-10. [CrossRef]

20. Wang, X.; Palazzo, D.; Carper, M. Ecological wisdom as an emerging field of scholarly inquiry in urban planning and design. Landsc. Urban Plan. 2016, 155, 100-107. [CrossRef]

21. Abubakar, I.R.; Bununu, Y.A. Low carbon city: Strategies and case studies. In Sustainable Cities and Communities. Encyclopedia of Sustainability in Higher Education; Springer Nature: Cham, Switzerland, 2020; pp. 366-376.

22. Hasan, M.A.; Abubakar, I.R.; Rahman, S.M.; Aina, Y.A.; Chowdhury, M.M.I.; Khondaker, A.N. The synergy between climate change policies and national development goals: Implications for sustainability. J. Clean. Prod. 2020, 249, 119369. [CrossRef]

23. Alshuwaikhat, H.M.; Abubakar, I. Towards a sustainable urban environmental management approach (SUEMA): Incorporating environmental management with strategic environmental assessment (SEA). J. Environ. Plan. Manag. 2007, 50, 257-270. [CrossRef]

24. Costanza, R.; Graumlich, L.; Steffen, W.; Crumley, C.; Dearing, J.; Hibbard, K.; Leemans, R.; Redman, C.; Schimel, D. Sustainability or Collapse: What Can We Learn from Integrating the History of Humans and the Rest of Nature. AMBIO 2007, 36, 522-527. [CrossRef]

25. Campbell, S. Green Cities, Growing Cities, Just Cities? Urban Planning and the Contradictions of Sustainable Development. J. Am. Plan. Assoc. 2007, 62, 296-312. [CrossRef]

26. Song, Y.; Stead, D.; de Jong, M. New Town Development and Sustainable Transition under Urban Entrepreneurialism in China. Sustainability 2020, 12, 5179. [CrossRef]

27. Ye, Y.E.; Van Nes, A. The spatial flaws of new towns: Morphological comparison between a Chinese new and old town through the application of space syntax, spacematrix and mixed use index. ITU AZ J. Fac. Archit. (ITU Derg. A) 2014, 11, 1-20.

28. Firman, T. New town development in Jakarta Metropolitan Region: A perspective of spatial segregation. Habitat Int. 2004, 28, 349-368. [CrossRef]

29. Rumbach, A. Do new towns increase disaster risk? Evidence from Kolkata, India. Habitat Int. 2014, 43, 117-124. [CrossRef]

30. Lau, J.C.Y. Spatial mismatch and the affordability of public transport for the poor in Singapore's new towns. Cities 2011, 28, 230-237.

31. Zamani, B.; Arefi, M. Iranian new towns and their urban management issues: A critical review of influential actors and factors. Cities 2013, 30, 105-112. [CrossRef]

32. Ziari, K. The planning and functioning of new towns in Iran. Cities 2006, 23, 412-422. [CrossRef]

33. Stewart, D.J. Cities in the desert: The Egyptian new-town program. Ann. Assoc. Am. Geogr. 1996, 86, 459-480. [CrossRef]

34. Kwak, Y.; Park, C.; Deal, B. Discerning the success of sustainable planning: A comparative analysis of urban heat island dynamics in Korean new towns. Sustain. Cities Soc. 2020, 61, 102341. [CrossRef]

35. Wu, T.; Yang, B.; Zhang, C. China's New Town: 1979-2009. J. Urban Reg. Plan. 2011, 2, $19-43$.

36. Tan, X. New-town policy and development in China. Chin. Econ. 2010, 43, 47-58. [CrossRef]

37. Cai, X.; De Meulder, B.; Lin, Y.; Sun, H. New Towns' Planning and Construction in the Pre-Urbanization or Post-Urbanization Period: A Case Study of the New Towns' Development Process of Beijing. Sustainability 2020, 12, 3721. [CrossRef]

38. Wang, H.; Fan, J. Influence of Urban Development Stage of Beijing on the Development of New Towns. City Plan. Rev. 2007, 31, 20-24. 
39. Li, Y. The Rises and Falls of New Towns in Japan: History and Insights for China. Urban Plan. Int. 2017, 32, 18-25. [CrossRef]

40. Yokohari, M.; Amemiya, M.; Amati, M. The history and future directions of greenways in Japanese New Towns. Landsc. Urban Plan. 2006, 76, 210-222. [CrossRef]

41. Serghides, D.K. The wisdom of Mediterranean traditional architecture versus contemporary architecture-The energy challenge. Open Constr. Build. Tech. J. 2010, 4, 29-38. [CrossRef]

42. Rashid, M.; Ara, D.R. Modernity in tradition: Reflections on building design and technology in the Asian vernacular. Front. Archit. Res. 2015, 4, 46-55. [CrossRef]

43. Guttmann-Bond, E. Sustainability out of the past: How archaeology can save the planet. World Archaeol. 2010, 42, 355-366. [CrossRef]

44. Wan, L.; Ng, E. Assessing the Sustainability of the Built Environment in Mountainous Rural Villages in Southwest China. Mt. Res. Dev. 2016, 36, 4. [CrossRef]

45. Kakoty, S. Ecology, sustainability and traditional wisdom. J. Clean. Prod. 2018, 172, 3215-3224. [CrossRef]

46. Chowdhury, M.M.I.; Rahman, S.M.; Abubakar, I.R.; Aina, Y.A.; Hasan, M.A.; Khondaker, A.N. A review of policies and initiatives for climate change mitigation and environmental sustainability in Bangladesh. Environ. Dev. Sustain. 2020, 7, 1-29. [CrossRef]

47. Oshima, K.T. Rediscovering Japanese urban space in a world context. J. Urban Hist. 2016, 42, 623-633. [CrossRef]

48. AlQahtany, A.M.; Abubakar, I.R. Public perception and attitudes to disaster risks in a coastal metropolis of Saudi Arabia. Int. J. Disaster Risk Reduct. 2020, 44, 101422. [CrossRef] [PubMed]

49. Buell, L. Humble abodes of pre/industrial environmental memory: Thoreau, Stowe, Engels, and others. South Cent. Rev. 2018, 35, 12-25. [CrossRef]

50. Momete, D.C. Sustainable development and its concrete implications: From an ancient wisdom to a modern fashion. In Proceedings of the 11th WSEAS International Conference on environment, ecosystems and development, Brasov, Romania, 1 June 2013; pp. 252-257.

51. Wah, L. Ancient wisdom in modern design. Manag. Rev. 1998, 87, 13.

52. Dhingra, M.; Chattopadhyay, S. Advancing smartness of traditional settlements-case analysis of Indian and Arab old cities. Int. J. Sustain. Built Environ. 2016, 5, 549-563. [CrossRef]

53. Smith, M.E. The archaeological study of neighborhoods and districts in ancient cities. J. Anthropol. Archaeol. 2010, 29, 137-154. [CrossRef]

54. Widodo, J. Urban Environment and Human Behaviour: Learning from History and Local Wisdom. Procedia Soc. Behav. Sci. 2012, 42, 6-11. [CrossRef]

55. Abubakar, I.R.; Aina, Y.A. The prospects and challenges of developing more inclusive, safe, resilient, and sustainable cities in Nigeria. Land Use Policy 2019, 87, 104105. [CrossRef]

56. Dano, U.L.; Balogun, A.; Abubakar, I.R.; Aina, Y.A. Transformative urban governance: Confronting urbanization challenges with geospatial technologies in Lagos Metropolitan Area. Geo. J. 2020, 85, 1039-1056.

57. Whiteman, G.; Cooper, W.H. Ecological embeddedness. Acad. Manag. J. 2000, 43, 1265-1282.

58. Kim, D.K. The natural environment control system of Korean traditional architecture: Comparison with Korean contemporary architecture. Build. Environ. 2006, 41, 1905-1912. [CrossRef]

59. Barthel, S.; Isendahl, C. Urban gardens, Agriculture, and water management: Sources of resilience for long-term food security in cities. Ecol. Econ. 2013, 86, 224-234. [CrossRef]

60. Mazraeh, H.M.; Pazhouhanfar, M. Effects of vernacular architecture structure on urban sustainability case study: Qeshm Island, Iran. Front. Archit. Res. 2018, 7, 11-24. [CrossRef]

61. Guo, X.; Wang, J.P. Study of traditional architectural form adapt to the mountain environment research-Zhang Jiata ancient Village in Fangshan county of Shanxi. Appl. Mech. Mater. 2014, 477, 1144-1147. [CrossRef]

62. Okubo, T. Traditional wisdom for disaster mitigation in history of Japanese Architectures and historic cities. J. Cult. Herit. 2016, 20, 715-724. [CrossRef]

63. Bayoumi, O.A.M. Nubian Vernacular architecture \& contemporary Aswan buildings' enhancement. Alex. Eng. J. 2018, 57, 875-883.

64. Shaowen, H.; Hanqi, H. Ecological Cultures of Traditional Hani Villages. J. Landsc. Res. 2017, 6, 87-93.

65. Abubakar, I.R.; Dano, U.L. Sustainable urban planning strategies for mitigating climate change in Saudi Arabia. Environ. Dev. Sustain. 2020, 22, 5129-5152. [CrossRef] 
66. Jabareen, Y.R. Sustainable urban forms: Their typologies, models, and concepts. J. Plan. Educ. Res. 2006, 26, 38-52. [CrossRef]

67. Lin, J.; Cai, J.; Han, Y.; Liu, J. Identifying the conditions for rural sustainability through place-based culture: Applying the CIPM and CDPM models into Meibei ancient village. Sustainability 2017, 9, 1334. [CrossRef]

68. Smith, M.E. Form and meaning in the earliest cities: A new approach to ancient urban planning. J. Plan. Hist. 2007, 6, 3-47. [CrossRef]

69. Yassin, H.H. Livable city: An approach to pedestrianization through tactical urbanism. Alex. Eng. J. 2019, 58, 251-259. [CrossRef]

70. Sharifi, A.; Murayama, A. Changes in the traditional urban form and the social sustainability of contemporary cities: A case study of Iranian cities. Habitat Int. 2013, 38, 126-134. [CrossRef]

71. King, A. Avoiding ecological surprise: Lessons from long-standing communities. Acad. Manag. Rev. 1995, 20, 961-985. [CrossRef]

72. Chu, Y.C.; Hsu, M.F.; Hsieh, C.M. An example of ecological wisdom in historical settlement: The wind environment of Huazhai village in Taiwan. J. Asian Archit. Build. Eng. 2017, 16, 463-470. [CrossRef]

73. Zheng, S.; Han, B.; Wang, D.; Ouyang, Z. Ecological Wisdom and Inspiration Underlying the Planning and Construction of Ancient Human Settlements-Case Study of Hongcun UNESCO World Heritage Site in China. Sustainability 2018, 10, 1345. [CrossRef]

74. Lin, Y.; Weichu, H. Spatial Characteristics of Ancient Villages in Western Beijing Based on ASTER GDEM Data. J. Landsc. Res. 2018, 10, 128-134.

75. Ramzy, N.S. Morphological logic in historical settlements: Space syntax analyses of residential districts at Mohenjo-Daro, Kahun and Ur. Urban Design Int. 2016, 21, 41-54. [CrossRef]

76. Siti Rukayah, R.; Puguh, D.R.; Susilo, E.S.; Indraswara, M.S. Local Wisdom of the Native Settlement as A Main Gate in the Northern Axis of Javanese City Center in Semarang. In IOP Conference Series: Earth and Environmental Science; IOP Publishing: Bristol, UK, 2018; Volume 152.

77. Zacharias, J.; Lei, Y. Villages at the urban fringe-the social dynamics of Xiaozhou. J. Rural Stud. 2016, 47, 650-656. [CrossRef]

78. Ranaweera, M.P. Sustainable development, ancient wisdom and Sri Lankan technology. In Proceedings of the International Conference on Sustainable Built Environment (ICSBE-2010), Kandy, Sri Lanka, 14-26 December 2010.

79. Sprague, D.S. Land-use configuration under traditional agriculture in the Kanto Plain, Japan: A historical GIS analysis. Int. J. Geogr. Inf. Sci. 2013, 27, 68-91. [CrossRef]

80. Mu'azu, N.D.; Abubakar, I.R.; Blaisi, N.I. Public acceptability of treated wastewater reuse in Saudi Arabia: Implications for water management policy. Sci. Total Environ. 2020, 721, 137659. [CrossRef] [PubMed]

81. Yu, K. Green infrastructure through the revival of ancient wisdom. Landsc. Archit. Front. 2018, 6, 3. [CrossRef]

82. Muhammed, Z.; Abubakar, I.R. Improving the Quality of Life of Urban Communities in Developing Countries. Responsible Consumption and Production. In Encyclopedia of the UN Sustainable Development Goals; Springer Nature: Cham, Switzerland, 2019; pp. 357-370.

83. Abubakar, I.R.; Lawanson, T.O.; Usman, A.S. Urban Planning Practices in Lagos. In The Routledge Handbook of Planning Megacities in the Global South; Rukmana, D., Ed.; Taylor and Francis: New York, NY, USA, 2020; pp. 382-396.

84. Rai, P.T. Townships for Sustainable Cities. Procedia Soc. Behav. Sci. 2012, 37, 417-426. [CrossRef]

85. UN-Habitat. A New Strategy of Sustainable Neighbourhood Planning: Five Principles; Urban Planning Discussion Note 3; United Nations Human Settlements Programme: Nairobi, Kenya, 2014.

86. Gazzeh, K.; Abubakar, I.R. Regional disparity in access to basic public services in Saudi Arabia: A sustainability challenge. Utilities Policy 2018, 52, 70-80. [CrossRef]

Publisher's Note: MDPI stays neutral with regard to jurisdictional claims in published maps and institutional affiliations. 